\title{
CHANGES IN THE RELATIONSHIP BETWEEN ICT USE AND ECONOMIC DEVELOPMENT IN EU MEMBER STATES 2010-2016
}

\author{
Miklós Herdon ${ }^{1}$, Adrián Csordás ${ }^{2}$ \\ ${ }^{1,2}$ University of Debrecen, Faculty of Economics and Business, \\ Institute of Applied Informatics and Logistics, 4032 Debrecen, Böszörményi út 138. Hungary \\ 'herdon.miklos@econ.unideb.hu \\ ${ }^{2}$ csordas.adrian@econ.unideb.hu
}

\begin{abstract}
In this study, we examined some ICT indicators of the EU Member States between 2010 and 2016 based on data of the World Bank and Eurostat. We wanted to know, how can the EU Member States be grouped according to these indicators, and which group can Hungary belong to. With the help of international literature reviews, three indicators were chosen. According to these we created three groups (underdeveloped, developing, developed) with the K-Mean cluster method that is classified by their level of development. Interesting changes took place during the period under review. By the end of the analyzed period, six countries lost their "developed" rating among others some founding members. There were also interesting changes in the clusters. The value of some indicators increased more than $40 \%$ in some cases, surprisingly, only in one case measured reduction. The proportion of ICT specialists decreased in developing countries (by 1\%). The highest growth rate was observed in the developed countries in e-commerce. Because of the high proportion of ICT professionals and the share of e-commerce in the developed cluster we assumed that service would be the dominant sector. The two-sample t-test did not confirm our hypothesis. We supposed the focus in developing countries will be on the industry, due we think the developed countries started to outsource their SSCs (shared service centers) to less developed countries. With the help of a statistical indicator, we confirmed our assumption, but the result not so convincing since the significant level is only $11 \%$. Although we thought that the underdeveloped group of countries was based on agriculture, statistical studies did not support our hypothesis.
\end{abstract}

Keywords: ICT, EU, Services, Agriculture, Industry

(JEL Classification: O13, O14, O52) 


\section{INTRODUCTION}

The Internet transformed not only how people live, work, socialize and meet, but also modified how countries develop and grow (MCKINSEY, 2011). The Internet can be called the base of Information and Communication Technology (ICT), which is appeared in the early 2000s. ICT overturns the future of the world by reducing geographic boundaries and bringing culture and societies closer to each other (NASIR and KALIRAJAN 2016). It eliminates and sets limits between individuals and groups at the same time (PEPPER and GARRITY 2015) and thus creates new opportunities for cross-industry relationships (NAVEED et al. 2017). Digital developments such as cloud services, mobile services, and artificial intelligence from the last decade have further expanded its opportunities (WATANABE et al. 2018).

ICT affects economic growth, productivity, usefulness, and efficiency from many different points of view. The most obvious such effects are the number of people employed in the ICT sector and the level of spending on the ICT sector. (DOUCEK et al. 2014).

Naturally, it has a serious impact on gross domestic product (GDP), international cooperation in finance, trade, foreign direct investment (FDI) and Poverty reduction (BON et al. 2016).

According to "New Theory of Economic Growth" (RAHAMAN and CHAKRABORTY 2015), FDI can be a catalyst and growth engine for various economies. DUONG (2017) says, it makes possible to access the new technologies, increases the stock of human capital, and creates new job opportunities. In addition, FDI can affect the rate of growth and level of per capita.

ICT has realized the globalization and plays a significant role in the development of it. Thanks to market liberalization, competition is increased as well as the importance of cost. Furthermore, the economy scale became larger (ROHMAN, 2013). Multinational enterprises promotion the globalization worldwide and realize the increment of it.

Because of this wide-ranging impact of ICT, scientists have placed great emphasis on the limitations of GDP statistics, which should help us measure the growth of the digital economy (IMF, 2017).

The OECD also expressed concerns about the limitations of GDP statistics. According to AHMAD et al. (2016), the question is whether GDP and productivity can measure the changes in the digital economy.

LOWREY (2011) says the internet promotes the consumption of free culture, which brings utility and happiness. However, these goods we cannot measure with GDP. Such goods, such as happiness, are measured by the United Nations with indicators such as the Happy Planet Index (HPI).

The development of the Internet is continuing and moves our planet towards an IoT (Internet of Things)-based society (NAVEED et al. 2017). The importance of business models and digital business strategies are going to be even more important, because of these challenges and huge interest in the IoT (BHARADWAJ et al. 2013).

\section{Objectives}

The diffusion of ICT is used to express the radical and influential changes in different aspects of social and economic lives. The present study examines the impact of some ICT indicators on the level of development. The goals of the research are, to get to know:

- How can EU Member States be grouped according to ICT indicators?

- Do countries focus on different sectors depending on their level of digital development?

\section{Theoretical background}

information and Communication Technology refers to various sets of technology tools and resources that are capable of communicating, producing, distributing, storing and managing information (WONSEOK et al. 2018). The ICT collection category includes, but is not limited to, telecommunications used by technology, media, intelligent management systems, transmission systems and networkbased control and monitoring functions. It is developed due the information technology and the Internet. It began to spread widely in the 1990s (NEMESLAKI, 2012).

The European Information Technology Observatory (EITO, 2013) divides the ICT market into three parts: Telecommunications (end-user telecommunication equipment, supplier services, network equipment), consumer electronics (digital cameras, televisions, navigation systems and other devices) and information technology (IT hardware and software services).

The development of ICT seems to be necessary for economic growth and the development of countries for numerous reasons. For example with the help of new technologies increase the speed of data transmission, so we can more information share in the same amount of time. There are no more borders between the buyers and the sellers, that is why the people have bigger access to the international supply of goods (SEPEHRDOUST, 2018).

Many authors have analyzed the impact of ICT on economic growth in recent decades. There is evidence of the positive impact of ICT on growth in the economy since the mid-1990s (FARHADI et al. 2012). OLINER and SICHEL (2000) use ICT capital components such as computer hardware, software and telecommunications equipment as well as capital and labor as inputs and empirically prove that the contribution of ICT to economic growth was very high in the 1990s end. According to POHJOLA (2002), the most important factors in US economic growth in the 1990s were the quality of production and ICT use.

Researchers agree that ICT has a major impact on production and business processes and thus it is a major driver of economic growth. The position of researchers is not as uniform as to the form of the effect. We can distinguish two main lines of this question. The first approach argues that, since ICT represents a special type of capital good when 
companies and governments increase investments in ICT, this will raise labour and total factor productivity. These investments complement or replace investments in other capital assets and increase the production capacity of ICTusing sectors and industries. The other approach is that economic growth is driven by the emergence of new sectors incorporating new technologies, such as the ICT production sector itself. According to this approach, growth has two sources:

- New sectors exhibit higher growth rates of value-added, productivity and incomes. Because of this, it will function as a source of growth for the whole economy.

- New sectors change other sectors of the economy by changing relative prices and raises productivity. These provide a new set of inputs, which cause the introduction of new or improved products or new production methods (KARLSSON et al. 2010).

According to Jorgensen (JORGENSEN et al. 2002), there is a third potential indirect growth impact. It is called spillover effects. An increase in total factor productivity can be realized, when the spillover effects of technological advances from industries producing ICT to industries using ICT takes place.

There are studies, which indicate that the productivity effect of ICT is not only significant and positive but increasing in the private and public sector too (TARUTEA and GATAUTIS 2014).

CONSOLI (2012) grouped the impact of ICT on companies according to scientific literature. He categorized its main effects into 4 groups (Table 1).

Table 1: Impact of ICT in the private sector

\begin{tabular}{|l|l|l|l|}
\hline Expansion & Growth & New products & Performance \\
\hline $\begin{array}{l}\text { Organization } \\
\text { expansion }\end{array}$ & $\begin{array}{l}\text { Productivity } \\
\text { growth } \\
\text { Improvement of } \\
\text { supply chain } \\
\begin{array}{l}\text { International } \\
\text { communication } \\
\text { growth }\end{array}\end{array}$ & $\begin{array}{l}\text { New products/ } \\
\text { services } \\
\text { Product quality } \\
\text { Customer } \\
\text { satisfaction }\end{array}$ & $\begin{array}{l}\text { Efficiency, } \\
\text { effectiveness, } \\
\text { and } \\
\text { competitiveness } \\
\text { Innovative } \\
\text { business } \\
\text { Intangible } \\
\text { benefits }\end{array}$ \\
\hline
\end{tabular}

Source: According to CONSOLI (2012), own edition

According to LEE et al. (2005), the impact of ICT on economic growth is significant in many advanced and newly industrialized economies, but this effect is not present in developing countries.

In contrast, ANTONELLI (1991) believes that developing countries can realize more benefits from ICT than developed countries. SEO AND LEE (2006) say the switch from dominant technology to the new ICT-based paradigm attends significant costs for developed countries, while this cost is relatively lower in developing countries.

In general, the empirical evidence of the impact of ICT on economic growth can be divided into two groups based on the methodology. The first method of proof is the use of growth accounting techniques. This weighs on the growth of inputs by the share of production value and expresses the contribution of ICT to economic growth in percentage points. The second method is to use cross-regression techniques to examine the impact of ICT on economic growth (FARHADI et al. 2012).

\section{MATERIALS AND METHODS}

For us to analyze the context of information and communication technologies in macroeconomics, we need a comprehensive dataset consisting of variables measuring ICT indicators and macroeconomic indicators of several countries globally. National statistical offices often estimate domestic values in their own national currencies. That is why they are not directly international comparable. The data we used was compiled after reviewing the databases of several international organizations. The main sources of our database were the European Statistical Office (Eurostat) and the World Bank. Due to the limited accessibility of ICTs data for developing countries, we analyzed only 28 members of the European Union. The period under review is from 2010 to 2016 because only during this time were all the indicators available (and all the data complete) for the EU Member States. The variables which were used in our research are shown in Table 2.

Table 2: Descriptive of variables used in models

\begin{tabular}{|c|c|c|c|}
\hline Variable & Description & Measurement & Data Source \\
\hline ict spec & $\begin{array}{l}\text { Employed ICT } \\
\text { specialists (\% of } \\
\text { total employment) }\end{array}$ & \multirow{3}{*}{$\begin{array}{l}\text { The Eurostat } \\
\text { is responsible } \\
\text { for collecting } \\
\text { data and } \\
\text { calculating the } \\
\text { rates. (National } \\
\text { Statistical } \\
\text { Offices } \\
\text { measure it.) }\end{array}$} & \multirow{3}{*}{ Eurostat } \\
\hline onl sell & $\begin{array}{l}\text { Enterprises selling } \\
\text { online (at least } 1 \% \\
\text { of turnover)(\% of } \\
\text { enterprises) }\end{array}$ & & \\
\hline turno e-com & $\begin{array}{l}\text { Enterprises total } \\
\text { turnover from } \\
\text { e-commerce (\%of } \\
\text { turnover) }\end{array}$ & & \\
\hline agr & $\begin{array}{l}\text { Agriculture, value } \\
\text { added ( } \% \text { of GDP) }\end{array}$ & \multirow{3}{*}{$\begin{array}{l}\text { Weighted } \\
\text { average }\end{array}$} & \multirow{3}{*}{ World Bank } \\
\hline man & $\begin{array}{l}\text { Manufacture, } \\
\text { value added (\% of } \\
\text { GDP) }\end{array}$ & & \\
\hline ser & $\begin{array}{l}\text { Services, value } \\
\text { added (\% of GDP) }\end{array}$ & & \\
\hline
\end{tabular}

Source: Eurostat and World Bank, own edition

Other indicators such as Big Data, Cloud Computing, ICT security would have been useful, but there was not enough available data for all Member States during the period under review.

SPSS software was used for the examination. We classified the countries of the European Union with 
the K-Mean method according to the indicators of the literature review. The classification of similar things is called clustering, where the items which are alike placed into groups. The aim of this is to classify the observed units into relatively homogeneous groups, which are based on certain aspects. Among the hierarchical clustering methods, Ward and the average chain method are popular, but they increasingly become "supplementary" to non-hierarchical methods. The ideal solution is to run a hierarchical method first, to find out how much the ideal number of clusters would be, then we should run the non-hierarchical method where we set that value to the number of groups. In our case, the singular use of the K-Mean method was sufficient, because the aim was to define a predetermined number of groups (underdeveloped, developing and developed) (SAJTOS and MITEV, 2007). The K-Means clustering algorithm uses $\mathrm{k}$ as a parameter, divide $\mathrm{n}$ objects into $\mathrm{k}$ clusters. The objects from the same cluster are similar to each other however differing from the other objects which belong to the other groups. The algorithm tries to find the centers of the group, $(\mathrm{C} 1, \mathrm{C} 2$, $\mathrm{C} 3, \ldots \ldots . \mathrm{Ck}$ ), such that the sum of the squared distances of each data point, $\mathrm{xi}, 1 \leq \mathrm{i} \leq \mathrm{n}$, to its nearest cluster center $\mathrm{Cj}, 1 \leq \mathrm{j} \leq \mathrm{k}$, is minimized (ARPIT et al., 2017).

Two-sample t-test was used to examine whether the mean values of the two random samples differ significantly from each other. There are two prerequisites for applying this test, these are focused on the normal distribution and the standard deviation. If the Levene test is greater than 0.05 , then the standard deviation is the same and the twosample t-test can be used, otherwise, we have to run the Weich d-test (HOWELL, 2013).

\section{RESULTS AND DISCUSSION}

In this research, ICT is in focus, so for group creation, we studied international researches to get to know which indicators are strongly connected with developing. According to these papers (Table 3), we defined variables for SPSS such as ICT specialists. online sell and e-commerce.

Table 3: Examined variables from the literature review

\begin{tabular}{|l|l|}
\hline \multirow{5}{*}{ ICT specialists } & $\begin{array}{l}\text { SCHIVARDI and SCHMITZ } \\
2018, \\
\text { KAUR et al. 2017, } \\
\text { LAU et al. 2016, }\end{array}$ \\
\hline Online sell & ZMUK 2015, ARIFF et al. \\
& 2013, ARLI et al. 2018, \\
\hline \multirow{5}{*}{ E-commerce } & MAYANK and ZILLUR 2017, \\
& RAHAYU and DAY 2016, \\
& CARMEN et al. 2016, \\
\hline
\end{tabular}

Source: own edition

We examined, how did the countries change (if they changed) their place according to the above-mentioned variables the period under review. Using the K-Mean cluster method, three clusters were generated by SPSS in the year 2010. The final cluster centers are shown in Table 4.

Table 4: Underdeveloped, developing and developed clusters were generated by the K-Mean cluster method in the year of 2010.

\begin{tabular}{|c|c|c|c|}
\hline & Underdeveloped & Developing & Developed \\
\hline ict_spec & 1,82 & 3,73 & 3,09 \\
\hline online_sell & 5,83 & 11,44 & 22,30 \\
\hline e_commerce & 4,50 & 13,22 & 16,30 \\
\hline
\end{tabular}

Source: Based on SPSS data, own edition

As can be seen in the table above, the values of the undeveloped group for all three variables are lower than the values for the other two clusters. The biggest difference was measured in the field of e-commerce. Surprisingly, the proportion of ICT professionals in the group of developing countries is higher than the same value in the developed countries, and the value of e-commerce is only $3 \%$ behind the same area in the developed group. In this case, the disadvantage of online sell is the biggest compared to the developed group.

Table 5. shows the classification of countries according to the examined indicators.

Table 5: The EU members are listed in clusters by SPSS in the year of 2010. (F: founder. Missing: Greece. Luxembourg ${ }^{\mathrm{F}}$, Malta)

\begin{tabular}{|l|l|l|}
\hline Underdeveloped & Developing & Developed \\
\hline Bulgaria & Austria & Belgium \\
\hline Cyprus & Estonia & Croatia \\
\hline ItalyF & Finland & Czech Republic \\
\hline Latvia & France ${ }^{\mathrm{F}}$ & Denmark \\
\hline Poland & Hungary & Germany \\
\hline Romania & Slovakia & Ireland \\
\hline & Slovenia & Lithuania \\
\hline & Spain & Netherlands \\
& United Kingdom & Portugal \\
\hline & & Sweden \\
\hline & & \\
\hline
\end{tabular}

Source: Based on SPSS data, own edition

It is very surprising that Italy, as one of the founders of the EU, has been among the underdeveloped countries. Nor can it be expected that the other founder member France, was only in the developing group.

We repeated the same methods for data of 2016 to see, how the values and the members changed. The final cluster centers are seen in Table 6 . 
Table 6: Underdeveloped, developing and developed clusters were generated by the K-Mean cluster method in the year 2016.

\begin{tabular}{|l|l|l|l|}
\hline & Underdeveloped & Developing & Developed \\
\hline ict_spec & 2,18 & 3,66 & 4,50 \\
\hline online_sell & 8,50 & 16,80 & 27,20 \\
\hline e_commerce & 6,17 & 15,00 & 27,80 \\
\hline
\end{tabular}

Source: Based on SPSS data, own edition

We can see, the values underlying the clusters have changed significantly compared to the data of 2010 .

The proportion of online sales companies almost doubled $(45 \%)$ in underdeveloped countries during the period under review and companies' revenue from e-commerce also increased by $37 \%$. In the developing countries, the proportion of ICT professionals decreased slightly (1\%), while the share of online sales companies become nearly two times bigger (47\%). In developed countries, the share of ICT specialists increased greatly $(46 \%)$, while the revenue from e-commerce increased significantly (70\%).

Not only the values of clusters have changed, but also the elements of the groups. This is seen in Table 7.

Table 7: The EU members are listed in clusters by SPSS in the year of 2016.

(F: founder, $\downarrow$ : setback, Missing: Finland, Luxembourg ${ }^{\mathrm{F}}$ )

\begin{tabular}{|l|l|l|}
\hline Underdeveloped & Developing & Developed \\
\hline Bulgaria & Austria & Belgium $^{\mathrm{F}}$ \\
\hline Cyprus & Croatia $\downarrow$ & Czech Republic \\
\hline Greece & Estonia & Denmark \\
\hline Italy & F & France \\
\hline Latvia & Germany ${ }^{\mathrm{F}} \downarrow$ & Ireland \\
\hline Romania & Hungary & Sweden \\
\hline & Lithuania & \\
\hline & Malta & \\
\hline & Netherlands ${ }^{\mathrm{F}} \downarrow$ & \\
\hline & Poland $\downarrow$ & \\
\hline & Portuga $\downarrow$ & \\
\hline & Slovakia & \\
\hline & Slovenia & \\
\hline & Spain & \\
\hline & United Kingdom & \\
\hline & & \\
\hline
\end{tabular}

Source: Based on SPSS data, own edition

While in 2010 the differences between group numbers were not so great, by 2016 the size of the developing group had grown significantly due to the decline in the members of the former developed group.

\section{The impact of development on the sectors}

Due to the high proportion of ICT professionals and the share of e-commerce, we assumed that service would be the dominant sector in developed countries. The decline in ICT practitioners in developing countries is likely to be related to the outsourcing of SSCs (shared service centers) to countries with lower costs (less developed). Based on this, we supposed the focus in developing countries will be on the industry. Although outsourcing of SSCs has probably already begun in the underdeveloped countries, it is nonetheless a long-term process which, in our opinion, should not call into question the dominance of agriculture (in the short term). It is also important to note that there are a number of knowledge-intensive areas other than SSCs, which are specific to developed countries. To test these hypotheses, two-sample t-tests were used. This is illustrated in Table 8.

Table 8: The examination of dominant sectors with a twosample t-test (Only these countries were included in the analysis, which belongs to the same group in both years. $t$ value: $\mathbf{1 , 6 5 )}$

\begin{tabular}{|c|c|c|}
\cline { 2 - 3 } \multicolumn{1}{c|}{} & Sectors & Empirical t value \\
\hline \multirow{4}{*}{ Developed } & service & $-0,671$ \\
\cline { 2 - 3 } & agriculture & no significant value \\
\cline { 2 - 3 } & industry & no significant value \\
\hline \multirow{4}{*}{ Developing } & service & $-3,01$ \\
\cline { 2 - 3 } & agriculture & 1,608 \\
\cline { 2 - 3 } & industry & 2,582 \\
\hline \multirow{3}{*}{ Undeveloped } & service & no significant value \\
\cline { 2 - 3 } & agriculture & no significant value \\
\cline { 2 - 3 } & industry & $-1,066$ \\
\hline
\end{tabular}

Source: Based on SPSS data, own edition

For the first hypothesis which focused on developed countries, the calculated $t$ value for the service sector was lower than the critical $t$ value which means the difference in means is only chance, so we cannot say services are more dominant than the others. However according to Szirmai in developed countries services account for $70 \%$ of GDP (SZIRMAI, 2012). In the other two sectors, we did not get significant values.

In the second assumption which concentrated on the developing cluster, the critical t value is lower in the case of the industry than the empirical t values, so in developing countries, unlike in other countries, the added value of this sector is higher, than in the other sectors. It is important to note that the two-sample t-test result is significant but its value is only $11 \%$. SZIRMAI (2012) says it is undeniable that industry is an important driver 
of growth in most developing countries, however, we can not call it the engine of development, as data on capital intensity and labor productivity do not support it. In the other two cases, we measured that the empirical t values are lower than the critical $t$ value, so these means the differences in means are only chance.

In the case of the last hypothesis for the underdeveloped group, we did not measure any significant value for agriculture, so we can say nothing about this sector. TIMMER (2009) says, as per capita income increases in a country, the share of agriculture in GDP decreases. It also proves that agriculture should be dominant in underdeveloped countries. There is no country in Europe which would be a member of the Least Developed Countries, in spite of this agriculture is marked as the backbone of the economy in most African countries. According to the United Nations, this sector belongs to $30-60 \%$ of the GDP in these states (UNITED NATIONS, 2007). In the case of services, we did not get any significant value, however, in the case of the industry, we measured a low empirical $t$ value, which is lower than the critical $t$ value. It means this sector is not more dominant than the sectors of the other clusters.

\section{REFERENCES}

Ahmad N, Schreyer P. (2016): Are GDP and Productivity Measures up to the Challenges of the Digital Economy? International Productivity Monitor 30, Spring, pp. 4-27.

Antonelli C. (1991): The diffusion of advanced telecommunications in developing countries: (Development Centre of the O.E.C.D., Paris), pp. 111, ISBN 92-64-13578-2

Ariff M. S. M., Yan N. S., Zakuan N., Bahari A. Z., Jusoh A. (2013): Web-based Factors Affecting Online Purchasing Behaviour. IOP Conference Series: Materials Science and Engineering, 46, 012038. http://dx.doi.org/10.1088/1757$899 x / 46 / 1 / 012038$

Arli D, Bauer C, Palmatier R. W. (2018): Relational selling: Past, present and future. Industrial Marketing Management, 69, pp. 169-184. http://dx.doi.org/10.1016/j.indmarman.2017.07.018

Arpit B, Mayur S, Shalini G. (2017): Improved K-mean Clustering Algorithm for Prediction Analysis using Classification Technique in Data Mining, International Journal of Computer Applications (0975 - 8887) Volume 157 - No 6, January 2017, http://dx.doi. org/10.5120/ijca2017912719

Bharadwaj A, Sawy O. A. E., Pavloyu P. A., Venkatraman N. (2013): Digital business strategy: Toward a next generation of insights, MIS Quarterly, 37, pp. 471-482. https://dx.doi. org/10.25300/MISQ/2013/37:2.3

Bon A, Akkermans H, Jaap G. (2016): Developing ICT services in a low-resource development context. Complex Systems Informatics and Modeling Quarterly No 9 (2016)(12): pp.84109, https://dx.doi.org/10.7250/csimq.2016-9.05

Carmen M. L. L., Shan-Ling P, Sue N, Lili C. (2016): The Emergence of Self-Organizing E-Commerce Ecosystems in Remote Villages of China: A Tale of Digital Empowerment for
Rural Development, MIS Quarterly 40(2): pp.475-484, https:// dx.doi.org/10.25300/MISQ/2016/40.2.11

Consoli D. (2012): Literature analysis on determinant factors and the impact of ICT in SMEs. Procedia - Social and Behavioral Sciences, 62, pp. 93-97. http://dx.doi.org/10.1016/j. sbspro.2012.09.016

Doucek P, Fischer J, Novotný O. (2014): ICT and Economy, pp. 55-63, IDIMT-2014 Networking Societies - Cooperation and Conflict, Podebrady Czech Republic, Trauner Verlag Austria

Duong V. H. (2017): Two-way relationship between FDI and Vietnam's economic growth during 1986-2012. Economic Studies, 448(9), pp. 25-35., https://dx.doi.org/10.7250/csimq.2016-9.05

EITO (2013): ICT Market Report 2012/13 Definitions and Methodology, 36, accessed 10.03.2019., https://www.eito.com/ EITO-Report2012/13

Farhadi M, Ismail R, Fooladi M. (2012): Information and Communication Technology Use and Economic Growth. PLOS ONE 7, 1-7, https://dx.doi.org/10.1371/journal.pone.0048903

Howell D. C. (2013): Statistical methods for psychology, Belmont, California : Wadsworth Cengage Learning, 8th ed. ISBN 1111835489

International Monetary Fund (IMF) (2018): Measuring the Digital Economy, accessed: 30.03.2019., www.imf.org

Jorgensen D.W., Ho M.S., Stiroh K.J. (2002): Projecting Productivity Growth: Lesson from the US Growth Resurgence, Federal Reserve Bank of Atlanta Economic Review, Third Quarter, pp. 1-13.

Karlsson C, Maier G, Trippl M, Siedschlag I, Owen R, Murphy G. (2010): ICT and Regional Economic Dynamics: A Literature Review, https://dx.doi.org/10.2791/46419

Kaur H, Lechman E, Marszk A. (2017): Catalyzing Development through ICT Adoption: The Developing World Experience, https://dx.doi.org/10.1007/978-3-319-56523-1

Lau S. K., Winley G. K., Leung N. K. Y., Tsang N, Lau S. Y., (2016): An exploratory study of expectation in IT skills in a developing nation: Vietnam. Journal of Global Information Management, 24 (1), 1-13.

Lee S. T., Gholami R, Tong T. Y., (2005): Time series analysis in the assessment of ICT impact at the aggregate level-Lessons and implications for the new economy. Information and Management, 42, 1009-1022. https://dx.doi.org/10.1016/j.im.2004.11.005

Lowrey A. (2011): Freaks, Geeks, and GDP, accessed: 30.03.2019, https://slate.com/business/2011/03/the-productivityparadox-why-hasn-t-the-internet-helped-the-american-economygrow-more.html

Mayank Y, Zillur R. (2017): Measuring consumer perception of social media marketing activities in e-commerce industry: Scale development \& validation, Telematics and Informatics Volume 34, Issue 7, November 2017, pp. 1294- 1307, https:// dx.doi.org/10.1016/j.tele.2017.06.001

McKinsey Global Institute (2011): Internet matters: The net's sweeping impact on growth, jobs, and prosperity, accessed: 30.03.2019., https://www.mckinsey.com

Nasir S, Kalirajan K. (2016): Information and Communication Technology-Enabled Modern Services Export Performances of Asian Economies. Asian Development Review, 33, https://dx.doi. org/10.1162/ADEV_a_00059 
Naveed K, Watanabe C, Neittaanmäki P. (2018): The transformative direction of innovation toward an IoT-based society - Increasing dependency on uncaptured GDP in global ICT firms, Technology in Society, Volume 53, https://dx.doi. org/10.1016/j.techsoc.2017.11.003

Nemeslaki A. (2012): Vállalati internetstratégia. 1-272, Akadémai Kiadó Budapest, ISBN:9789630591898

Oliner S. D., Sichel D. E. (2000): The resurgence of growth in the late 1990s: Is information technology the story? Journal of Economic Perspectives 14, 3-22. https://dx.doi.org/10.1257/ jep.14.4.3

Pepper R, Garrity J. (2015): ICTs, income inequality, and ensuring inclusive growth. in: The Global Information Technology Report 2015, accessed: 30.03.2019., http://www3.weforum.org/docs/ WEF_Global_IT_Report_2015.pdf

Pohjola M. (2002): The New Economy: Facts, Impacts, and Policies. Information Economics and Policy 14, 133-144. https:// dx.doi.org/10.1016/S0167-6245(01)00063-4

Rahayu R, Day J. (2016). E-commerce adoption by SMEs in developing countries: evidence from Indonesia. Eurasian Business Review, 7(1), pp. 25-41. https://dx.doi.org/10.1007/ s40821-016-0044-6

Rohman I.K. (2013): The globalization and stagnation of the ICT sectors in European countries: An input-output analysis, Telecommunications Policy Volume 37, Issues 4-5, May-June 2013, pp. 387-399, http://dx.doi.org/10.1016/j.telpol.2012.05.001

Sajtos L, Mitev A. (2007): SPSS Kutatási és adatelemzési kézikönyv, pp. 1-404, Alinea Kiadó

Schivardi F, Schmitz T. (2018): The IT Revolution and Southern Europe's Two Lost Decades, EIEF Working Papers Series 1805

Seo H, Lee Y. (2006): Contribution of information and communication technology to total factor productivity and externalities effects. Information Technology for Development, 12, pp. 159-173, https://dx.doi.org/10.1002/itdj.20021

Sepehrdoust H. (2018): Impact of information and communication technology and financial development on economic growth of OPEC developing economies, Kasetsart Journal of Social Sciences (2018) 1-6, https://dx.doi.org/10.1016/j.kjss.2018.01.008

Szirmai A. (2012): Industrialisation as an engine of growth in developing countries, 1950-2005. Structural Change and Economic Dynamics, 23(4), 406-420. https://dx.doi. org/10.1016/j.strueco.2011.01.005

Tarutėa A, Gatautis R. (2014): ICT impact on SMEs performance, Procedia - Social and Behavioral Sciences 110, pp. 1218 - 1225 https://dx.doi.org/10.1016/j.sbspro.2013.12.968

Timmer C. P. (2009): A World Without Agriculture: The Structural Transformation in Historical Perspective. Washington, D.C.: American Enterprise Institute Press.

United Nations (2007): United Nations Ministerial Conference of the Least Developed Countries Making Globalization Work for the LDCs Istanbul, 9-11 July 2007

Watanabe C, Tou Y, Neittaanmäki P. (2018): A new paradox of the digital economy - Structural sources of the limitation of GDP statistics, Technology in Society, https://dx.doi.org/10.1016/j. techsoc. 2018.05.004
Wonseok O, Alessandro A, Choon L. S. (2018): ICT Challanges and Opportunities in Building a 'Bright Society', Journal of the Association for Information Systems,19(2), 58-62 (2018)

Zmuk B. (2015): Selling Online by European Enterprises - Multivariate Analysis Approach, International Journal of Engineering Business Management, https://dx.doi. org $/ 10.5772 / 60108$ 